\title{
Effects of Carbonic Anhydrase Inhibition on Ventilation-Perfusion Matching in the Dog Lung
}

Erik R. Swenson, H. Thomas Robertson, and Michael P. Hlastala

Departments of Medicine and of Physiology and Biophysics, University of Washington, Seattle, Washington 98195

\section{Abstract}

Lung carbonic anhydrase (CA) permits rapid pH responses when changes in regional ventilation or perfusion alter airway and alveolar $\mathrm{PCO}_{2}$. These pH changes affect airway and vascular resistances and lung compliance to optimize the balance of regional ventilation $\left(\dot{V}_{A}\right)$ and perfusion $(\dot{Q})$ in the lung. To test the hypothesis that these or other CA-dependent mechanisms contribute to $\dot{\mathbf{V}}_{\mathrm{A}} / \dot{\mathbf{Q}}$ matching, we administered acetazolamide ( $25 \mathrm{mg} / \mathrm{kg}$ intravenously) to six anesthetized and paralyzed dogs and measured $\dot{\mathbf{V}}_{\mathbf{A}} / \dot{\mathbf{Q}}$ relationships before and after $\mathbf{C A}$ inhibition by the multiple inert gas elimination technique. Four other groups of dogs were studied to control for possible confounding effects of time under anesthesia and nonselective $\mathrm{CA}$ inhibition by acetazolamide: $(a)$ saline placebo as a control for duration of anesthesia, (b) $4 \% \mathrm{CO}_{2}$ inhalation to mimic systemic $\mathrm{CO}_{2}$ retention, (c) $1 \mathrm{mg} / \mathrm{kg}$ benzolamide (a selective renal CA inhibitor) or $0.5 \mathrm{meq} / \mathrm{kg} \mathrm{HCl}$ to mimic systemic metabolic acidosis, and (d) $500 \mathrm{mg} / \mathrm{kg} \mathrm{4,4'-dinitrostilbene-2,2'-}$ disulfonate (an inhibitor of red cell band 3 protein) to mimic the respiratory acidosis arising from an intracapillary block to rapid mobilization of plasma $\mathrm{HCO}_{3}^{-}$in $\mathrm{CO}_{2}$ exchange. Acetazolamide increased $\dot{\mathbf{V}}_{\mathrm{A}} / \dot{\mathrm{Q}}$ mismatch and reduced arterial $\mathrm{PO}_{2}$ measured at equilibrium but these did not occur in the control group. There was no deterioration in $\dot{\mathbf{V}}_{\mathbf{A}} / \dot{\mathbf{Q}}$ matching when systemic respiratory acidosis produced either by $\mathrm{CO}_{2}$ inhalation or 4,4'-dinitrostilbene-2,2'-disulfonate or metabolic acidosis (benzolamide or $\mathrm{HCl}$ ) were imposed to mimic the effects of acetazolamide apart from its inhibition of lung $\mathrm{CA}$. These results support the concept that lung $C A$ subserves $\dot{V}_{A} / \dot{Q}$ matching in the normal lung. ( $J$. Clin. Invest. 1993.92:702-709.) Key words: acetazolamide $\cdot$ carbon dioxide $\bullet$ pH $\bullet$ red cell anion exchange $\bullet$ acidosis

\section{Introduction}

Carbonic anhydrase (CA $)^{1}$ in the lung is found in the pulmonary capillaries (1) and in the alveolar $(2,3)$ and bronchial

Address correspondence to Erik R. Swenson, M.D., Pulmonary and Critical Care Medicine, Veterans Affairs Medical Center, 111-B, 1660 South Columbian Way, Seattle, WA 98108.

Received for publication 27 July 1992 and in revised form 12 January 1993.

1. Abbreviations used in this paper: (a-A)D, arterial-alveolar difference; CA, carbonic anhydrase; DNDS, 4,4'-dinitrostilbene-2,2'-disulfonate; $\mathrm{HPV}$, hypoxic pulmonary vasoconstriction; $\log \mathrm{SD}_{\mathrm{Q}}, \log \mathrm{SD}$ of the perfusion distribution; $\log \mathrm{SD}_{\mathrm{v}}, \log \mathrm{SD}$ of the ventilation distribution; $\dot{Q}$, perfusion; $\dot{\mathrm{Q}}_{\mathrm{S}} / \dot{\mathrm{Q}}_{\mathrm{T}}$, inert gas shunt; $\dot{\mathrm{V} A}$, ventilation; $\dot{\mathrm{V}}_{2}$, oxygen consumption; $\dot{\mathrm{V}}_{2}$, carbon dioxide production; $\dot{\mathrm{V}}_{\mathrm{D}} / \dot{\mathrm{V}}_{\mathrm{T}}$, dead space.

J. Clin. Invest.

(C) The American Society for Clinical Investigation, Inc.

0021-9738/93/08/0702/08 \$2.00

Volume 92, August 1993, 702-709 epithelia (4). A number of functions have been ascribed to lung tissue $\mathrm{CA}$, which is both membrane bound and cytosolic. Membrane-bound $\mathrm{CA}$ of the capillary luminal endothelium prevents plasma $\mathrm{PCO}_{2} / \mathrm{pH}$ disequilibrium with $\mathrm{CO}_{2}$ exchange during capillary transit (5-7). Intracellular and extravascular membrane bound CA, which account for $80-90 \%$ of total lung tissue activity ( 8 ) increase the efficiency of $\mathrm{CO}_{2}$ transfer across the alveolar-capillary membrane by enhancing the facilitated diffusion of $\mathrm{CO}_{2}(9-11)$ and reduce the swings in airway and alveolar $\mathrm{CO}_{2}$ with tidal breathing by increasing the effective $\mathrm{CO}_{2}$ buffering capacity of lung tissue (12). CA in the alveolar epithelium appears to be involved with secretion of acidic alveolar lining fluid which may be important for normal surfactant maturation and function in the fetal (13) and possibly in the adult lung (14).

We propose another function for lung CA: that of subserving $\mathrm{pH}$-dependent mechanisms of ventilation-perfusion $\left(\dot{\mathrm{V}}_{\mathrm{A}} / \dot{\mathrm{Q}}\right)$ matching. Several characteristics of the lung provide the rationale for the hypothesis that rapid translation of changes in alveolar and tissue $\mathrm{PCO}_{2}$ (brought about by changes in either local ventilation or perfusion) to changes in $\mathrm{pH}$ may be important in $\dot{\mathrm{V}}_{\mathrm{A}} / \mathrm{Q}$ regulation. First, hypoxic pulmonary vasoconstriction is potentiated by high $\mathrm{CO}_{2}$ and $\mathrm{H}^{+}(15)$. Second, even in the absence of hypoxia, airways and vasculature and alveolar surfactant are $\mathrm{pH}$ sensitive and respond very rapidly to changes in ambient $\left[\mathrm{H}^{+}\right]$and $\left[\mathrm{CO}_{2}\right](15-19)$. Third, recent data suggest that the lung, heart, and skeletal muscle display temporal fluctuations in regional perfusion (20-24). With short-term temporal fluctuations in regional perfusion and ventilation, the amount of $\mathrm{CO}_{2}$ delivered to or eliminated from a region and in parallel the amount of $\mathrm{O}_{2}$ taken up from or delivered to a region will vary and set new prevailing local $\mathrm{CO}_{2}$ and $\mathrm{O}_{2}$ tensions. If these fluctuations in regional ventilation and perfusion are not rapidly matched by appropriate directional changes in accompanying blood or gas flows, then additional $\dot{\mathrm{V}}_{\mathrm{A}} / \dot{\mathrm{Q}}$ heterogeneity may develop with an associated loss in gas exchange efficiency. To test this hypothesis, we examined whether inhibition of carbonic anhydrase would cause $\dot{\mathrm{V}}_{\mathrm{A}} / \mathrm{Q}$ mismatching in the lungs of normal dogs.

\section{Methods}

Animal instrumentation and support. These studies were performed on 30 mixed breed dogs (weight $22-28 \mathrm{~kg}$ ) under barbiturate anesthesia (20-30 mg pentothal sodium as an initial dose with supplemental doses, $1-2 \mathrm{mg} / \mathrm{kg}$ every hour ) and succinylcholine paralysis $(1 \mathrm{mg} / \mathrm{kg}$ every hour). The animals were intubated with a cuffed endotracheal tube. Femoral arterial and venous catheters were inserted, and a 7French thermal dilution Swan-Ganz catheter (Baxter Healthcare Corp., Irvine, CA) was passed into the pulmonary artery via a jugular vein. The animal's temperature was monitored by a rectal thermometer. Ventilation was administered by a piston pump ventilator at a tidal vol of $12-15 \mathrm{ml} / \mathrm{kg}$ and a rate of $15-18$ per min. The ventilator was programmed to deliver a single $30 \mathrm{ml} / \mathrm{kg}$ breath ( sigh vol) every $5 \mathrm{~min}$ to prevent atelectasis. Once an acceptable rate of ventilation was determined by arterial blood gas analysis (arterial pH, 7.39-7.45 and $\mathrm{PaCO}_{2}$, $30-35 \mathrm{mmHg}$ ), there were no further changes in ventilation during the 
course of the experiment. Expired minute ventilation was measured at the conclusion of the experiment using a Tissot spirometer (Warren E. Collins, Inc., Boston, MA). After completion of the experiment, the dogs were killed by an overdose of sodium thiopental.

Hemodynamics and respiratory gas exchange measurements. Pulmonary arterial pressures, systemic arterial pressures, airway pressures, and expired $\mathrm{PCO}_{2}$ and $\mathrm{PO}_{2}$ were continuously recorded on an eight channel recorder. At 15-min intervals, pulmonary arterial wedge pressures, thermodilution cardiac outputs, and mixed expired $\mathrm{PO}_{2}$ and $\mathrm{PCO}_{2}$ ( sampled at the end of a 3-liter mixing box ) were determined. $\mathrm{PO}_{2}$ and $\mathrm{PCO}_{2}$ in expired gas were measured by a mass spectrometer (Medical Gas Analyzer MGA-1 100; Perkin-Elmer Cetus Instruments, Norwalk, $\mathrm{CT}$ ). Blood $\mathrm{pH}$ and partial pressures of $\mathrm{O}_{2}$ and $\mathrm{CO}_{2}$ were measured in arterial and mixed venous blood on a blood gas analyzer (BMS-3; Radiometer America, Inc., Westlake, $\mathrm{OH}$ ) maintained at $37^{\circ} \mathrm{C}$. Blood gas measurements were corrected to the measured temperature using the Severinghaus nomogram (25). Hematocrits were measured using capillary tubes spun for $5 \mathrm{~min}$. Oxygen consumption $\left(\dot{\mathrm{VO}}_{2}\right)$ and carbon dioxide production $\left(\dot{\mathrm{VCO}}_{2}\right)$ were calculated by analysis of expired gases using appropriate temperature and humidity corrections.

Inert gas exchange measurements. $\dot{\mathrm{V}}_{\mathrm{A}} / \dot{\mathrm{Q}}$ relationships were determined by the multiple inert gas elimination technique (26) using a constant intravenous infusion ( $3 \mathrm{ml} / \mathrm{min}$ ) of a dilute solution of six inert gases (sulfur hexafluoride, ethane, cyclopropane, halothane, diethyl ether, and acetone) dissolved in 5\% dextrose solution. The inert gas mixture was administered by a constant infusion pump for at least $30 \mathrm{~min}$ before an experimental run. Simultaneous samples of arterial and mixed venous blood and mixed expired gas (drawn from the distal end of a heated 3-liter mixing box) were drawn over $30 \mathrm{~s}$ by constant withdrawal pumps. Triplicate samples were obtained over a 3-min interval. Expired gas samples were maintained at $40^{\circ} \mathrm{C}$ before analysis to avoid water condensation and loss of soluble gases. The concentrations of inert gases were measured on a gas chromatograph (3300; Varian, Walnut Creek, CA), equipped with a flame ionization detector and electron capture detector. The gas extraction method of Wagner et al. (27) was used to determine inert gas tensions in the blood samples.

Experimental protocols. Five groups of six dogs each were studied. After stabilization and a 30-min infusion of inert gases, baseline measurements of hemodynamics (cardiac output, heart rate, systemic and pulmonary pressures), ventilation and respiratory gas exchange (arterial and mixed venous blood gases, minute ventilation, airway pressures and oxygen consumption and carbon dioxide output) and inert gas exchange were taken. 1-h later after an experimental manipulation these measurements were repeated. The first group received a $25 \mathrm{mg}$ / $\mathrm{kg}$ intravenous dose of acetazolamide (28), a potent CA inhibitor, to inhibit lung carbonic anhydrase. The second series of dogs, given an equal volume of saline instead of acetazolamide, served as a control group to account for any effects of instrumentation and of time under anesthesia. This was necessary because in the other four groups, it was not possible to randomize the order of baseline and postexperiment measurements.

The remaining groups were studied to mimic the blood and systemic effects of acetazolamide that occur in addition to its inhibition of lung $\mathrm{CA}$, as it is not possible in an intact animal to inhibit lung CA selectively. The third group inhaled a $4 \% \mathrm{CO}_{2}$ gas mixture for $60 \mathrm{~min}$ to mimic the effects of systemic respiratory acidosis $\left(\mathrm{CO}_{2}\right.$ retention $)$ that occur with CA inhibition. The fourth group was given either a $1 \mathrm{mg} / \mathrm{kg}$ intravenous dose of benzolamide (28), an extremely hydrophilic nonpermeant selective inhibitor of renal carbonic anhydrase $(n=3)$, or 0.5 $\mathrm{meq} / \mathrm{kg}$ of $\mathrm{HCl}$ in saline $(n=3)$ to mimic the effects of systemic metabolic acidosis that occur with inhibition of CA by acetazolamide. The fifth group was given an intravenous dose of $500 \mathrm{mg} / \mathrm{kg} \mathrm{4,4^{ \prime } -}$ dinitrostilbene-2,2'-disulfonate (DNDS), an inhibitor of red cell anion exchange (29) to control for the effects of an intracapillary block to $\mathrm{CO}_{2}$ exchange in the lung and resultant $\mathrm{CO}_{2}$ retention, different in mechanism but qualitatively similar to that which occurs with red cell $\mathrm{CA}$ inhibition.
Data analysis. Respiratory gas exchange was assessed by analysis of arterial and mixed venous blood gases. Inert gas exchange was assessed by changes in the ventilation and perfusion distributions predicted by the 50-compartment model of Wagner and colleagues $(26,30)$. Inert gas shunt $\left(\dot{\mathrm{Q}}_{\mathrm{S}} / \dot{\mathrm{Q}}_{\mathrm{T}}\right)$ and dead space $\left(\dot{\mathrm{V}}_{\mathrm{D}} / \dot{\mathrm{V}}_{\mathrm{T}}\right)$, and the log standard deviations of the perfusion $\left(\log \mathrm{SD}_{\mathrm{Q}}\right)$ and the ventilation $\left(\log \mathrm{SD}_{\mathrm{v}}\right)$ distributions were calculated from the 50 compartment model. $\dot{\mathrm{V}}_{\mathrm{A}} / \dot{\mathrm{Q}}$ heterogeneity was also assessed by the arterial-alveolar difference area, (a-A)D area, derived from the retention and excretion data (31). All data are averaged from the three sets of inert gas measurements.

The gas exchange and hemodynamic data are presented as means \pm SE. The data were analyzed by ANOVA followed by posthoc tests corrected for multiple comparisons of similar data sets. A $P$ value $<0.05$ was considered a statistically significant difference.

\section{Results}

Effects of carbonic anhydrase inhibition. The hemodynamic, ventilatory, metabolic, and respiratory gas exchange effects of $25 \mathrm{mg} / \mathrm{kg}$ acetazolamide are shown in Tables I and II. Not included in tables I and II were the data on systemic arterial pressure $(120 \pm 10 \mathrm{mmHg})$, pulmonary capillary wedge pressure $(4 \pm 0.5 \mathrm{mmHg})$, hematocrit $(40 \pm 0.5 \%)$, respiratory rate $(16.5 \pm 0.5 / \mathrm{min})$, and rectal temperature $\left(39.1 \pm 0.2^{\circ} \mathrm{C}\right)$. These are pooled mean data for all five groups. There were no statistically significant differences within or between groups. Since ventilation was fixed, these dogs showed the typical mixed respiratory and metabolic acidoses reflecting the combined inhibition of red cell and renal CA. The arterial pH fell from 7.46 to 7.26 , with a rise in arterial $\mathrm{PCO}_{2}$ from 30.1 to $41.1 \mathrm{mmHg}$ and a fall in $\mathrm{HCO}_{3}^{-}$from 20.2 to $18.9 \mathrm{mM}$. The arterial $\mathrm{Po}_{2}$ fell from 95 to $89 \mathrm{mmHg}(P<0.05)$. There were no significant changes in body temperature, cardiac output, heart rate, vascular or airway pressures, and hematocrit. Oxygen consumption fell by a small $(\sim 7 \%)$ but statistically significant amount. By $1 \mathrm{~h}$, the initial drop in $\mathrm{CO}_{2}$ output ( $\sim 40 \%$ of baseline at 5 min after drug administration) had recovered almost to baseline; 177 $\mathrm{ml} / \mathrm{min}$ vs $162 \mathrm{ml} / \mathrm{min}$.

Inert gas exchange deteriorated with acetazolamide as assessed by several indices of $\dot{\mathrm{V}}_{\mathrm{A}} / \dot{\mathrm{Q}}$ mismatch (Table III). There were significant increases in the dispersions of ventilation $(\log$ $\left.\mathrm{SD}_{\dot{\mathrm{v}}}\right)$ and perfusion $\left(\log \mathrm{SD}_{\mathrm{Q}}\right)$ and the $(\mathrm{a}-\mathrm{A}) \mathrm{D}$ area without significant changes in dead space ventilation or shunt. Fig. 1 illustrates the ventilation and perfusion distributions using the 50-compartment model in a single dog showing the largest effect of $\mathrm{CA}$ inhibition. Although the arterial $\mathrm{PO}_{2}$ fell with acetazolamide, an apparent contradiction between the respiratory gas exchange data of Table II and the inert gas exchange data of Table III arises in the alveolar-arterial $\mathrm{Po}_{2}$ differences $\left(\mathrm{PA}_{\mathrm{O}_{2}}\right.$ $-\mathrm{Pa}_{\mathrm{O}_{2}}$ ) before and after acetazolamide as a rough measure of $\dot{\mathrm{V}}_{\mathrm{A}} / \mathrm{Q}$ heterogeneity. When one uses the classic alveolar gas equation to calculate alveolar $\mathrm{PO}_{2}\left(\mathrm{PA}_{\mathrm{O}_{2}}\right)$

$\mathrm{PA}_{\mathrm{O}_{2}}=\mathrm{PI}_{\mathrm{O}_{2}}-\mathrm{Pa}_{\mathrm{CO}_{2}} / \mathrm{R}$

where $\mathrm{PI}_{\mathrm{O}_{2}}$ is inspired $\mathrm{PO}_{2}$ ( $149 \mathrm{mmHg}$ : normal air fully saturated at $760 \mathrm{mmHg}$ barometric pressure) and $\mathrm{R}$ is the respiratory quotient $\left(\dot{\mathrm{V} C O}{ }_{2} / \mathrm{VO}_{2}\right.$ : see Table II) the alveolar-arterial $\mathrm{PO}_{2}$ differences are $25 \mathrm{mmHg}$ before and $6 \mathrm{mmHg}$ after acetazolamide. By this criterion, it would appear that $\dot{\mathrm{V}}_{\mathrm{A}} / \dot{\mathrm{Q}}$ mismatch was decreased with acetazolamide, in contrast to the inert gas indices of $\dot{V}_{A} / Q$ heterogeneity. However, the fundamental assumption underlying this equation, namely arterialalveolar $\mathrm{PCO}_{2}$ equivalence, no longer applies during CA inhibi- 
Table I. Hemodynamic, Ventilatory, and Metabolic Measurements

\begin{tabular}{|c|c|c|c|c|c|c|c|c|c|c|}
\hline & \multicolumn{2}{|c|}{ Acetazolamide } & \multicolumn{2}{|c|}{ Control } & \multicolumn{2}{|c|}{ Respiratory acidosis } & \multicolumn{2}{|c|}{ Metabolic acidosis } & \multicolumn{2}{|c|}{ DNDS } \\
\hline & Pre & Post & Pre & Post & Pre & Post & Pre & Post & Pre & Post \\
\hline \multirow[t]{2}{*}{ Ppa, mmHg } & 22 & 21 & 19 & 18 & 22 & 23 & 19 & 18 & 18 & 19 \\
\hline & (3) & (2) & (2) & (1) & (2) & (3) & (3) & (1) & (2) & (2) \\
\hline \multirow[t]{2}{*}{$\mathrm{HR}, \min ^{-1}$} & 160 & 158 & 170 & 165 & 152 & 151 & 166 & 172 & 162 & 166 \\
\hline & (5) & (6) & (4) & (5) & (3) & (5) & (6) & (4) & (4) & (3) \\
\hline \multirow[t]{2}{*}{$\dot{\mathrm{Q}}$, liters/min } & 4.9 & 5.1 & 6.0 & 5.9 & 5.7 & $6.4^{*}$ & 5.2 & $5.8^{*}$ & 5.3 & 5.5 \\
\hline & $(0.5)$ & $(0.3)$ & $(0.4)$ & $(0.5)$ & $(0.3)$ & $(0.4)$ & $(0.5)$ & $(0.6)$ & $(0.4)$ & $(0.4)$ \\
\hline \multirow[t]{2}{*}{$\dot{\mathrm{V}}_{\mathrm{E}}$, liters $/ \mathrm{min}$} & 5.8 & 5.8 & 6.5 & 6.5 & 6.4 & 6.4 & 6.3 & 6.3 & 6.0 & 6.0 \\
\hline & $(0.5)$ & $(0.5)$ & $(0.6)$ & $(0.6)$ & $(0.5)$ & $(0.5)$ & $(0.5)$ & $(0.5)$ & $(0.6)$ & $(0.6)$ \\
\hline \multirow[t]{2}{*}{ Paw, mmHg } & 13.0 & 12.9 & 11.0 & 11.2 & 11.0 & $11.5^{*}$ & 11.2 & 10.9 & 11.2 & 11.3 \\
\hline & $(1.1)$ & $(1.0)$ & (1.3) & (1.0) & $(1.2)$ & $(1.1)$ & (1.0) & (1.1) & $(0.9)$ & $(1.1)$ \\
\hline \multirow[t]{2}{*}{$\dot{\mathrm{v}} \mathrm{O}_{2}$, liters $/ \mathrm{min}$} & 0.186 & $0.172^{*}$ & 0.195 & 0.190 & 0.173 & $0.141^{*}$ & 0.183 & 0.183 & 0.173 & 0.170 \\
\hline & $(0.020)$ & $(0.015)$ & $(0.017)$ & $(0.015)$ & $(0.018)$ & $(0.014)$ & $(0.017)$ & $(0.019)$ & $(0.018)$ & $(0.017)$ \\
\hline \multirow[t]{2}{*}{$\dot{\mathrm{V}} \mathrm{CO}_{2}$, liters/min } & 0.177 & $0.162^{*}$ & 0.182 & 0.180 & 0.162 & $0.135^{*}$ & 0.170 & 0.171 & 0.159 & 0.155 \\
\hline & $(0.018)$ & $(0.180)$ & $(0.015)$ & $(0.018)$ & $(0.016)$ & $(0.014)$ & $(0.019)$ & $(0.016)$ & $(0.017)$ & $(0.018)$ \\
\hline
\end{tabular}

Mean $\pm(\mathrm{SE})$ are presented. ${ }^{*} P<0.05$, pre vs post. Ppa, mean pulmonary artery pressure; HR, heart rate; $\dot{\mathrm{Q}}$, cardiac output; $\dot{\mathrm{V}}_{\mathrm{E}}$, expired minute ventilation; Paw, peak airway pressure.

tion and causes the calculation to underestimate the arterial-alveolar $\mathrm{PCO}_{2}$ difference considerably. This assumption clearly does not hold during inhibition of red cell CA due to a significant state of $\mathrm{H}^{+} / \mathrm{HCO}_{3}^{-} / \mathrm{CO}_{2}$ disequilibrium as blood leaves the pulmonary capillaries $(32,33)$. The magnitude and direction of this disequilibration is such that in vivo and ex vivo equilibrium arterial blood gases will show a marked postcapillary rise in $\mathrm{PCO}_{2}$ (33). The proper $\mathrm{PCO}_{2}$ to use would be the end capillary $\mathrm{PCO}_{2}$ in equilibrium with alveolar $\mathrm{PCO}_{2}$. The closest approximation is end-tidal $\mathrm{PCO}_{2}$ which were $28 \pm 1.5$ and $25 \pm 1.6 \mathrm{mmHg}$ ( means $\pm \mathrm{SE}$ ), respectively, before and after acetazolamide. Substitution of these values for $\mathrm{PaCO}_{2}$ reveals a widening of the arterial-alveolar $\mathrm{PO}_{2}$ difference with acetazol- amide from 26 to $33 \mathrm{mmHg}$ consistent with increased $\dot{V}_{A} / Q$ mismatch.

Effects of instrumentation and time under anesthesia. This series of control dogs, similarly treated as the other groups except for no experimental intervention, showed no significant changes over time in any measure of hemodynamics, metabolic rate, respiratory or inert gas exchange (Tables I and II). The only difference was a baseline level of $\dot{V}_{\mathrm{A}} / \dot{\mathrm{Q}}$ mismatch somewhat greater but not statistically different from the other groups.

Effects of respiratory acidosis. The inhalation of $4 \% \mathrm{CO}_{2}$ achieved a similar degree of respiratory acidosis as occurred with acetazolamide; $\mathrm{PaCO}_{2}, 43$ vs $41 \mathrm{mmHg}(P=\mathrm{NS})$ and $\mathrm{pH}$,

Table II. Respiratory Gas Exchange Measurements

\begin{tabular}{|c|c|c|c|c|c|c|c|c|c|c|}
\hline & \multicolumn{2}{|c|}{ Acetazolamide } & \multicolumn{2}{|c|}{ Control } & \multicolumn{2}{|c|}{ Respiratory acidosis } & \multicolumn{2}{|c|}{ Metabolic acidosis } & \multicolumn{2}{|c|}{ DNDS } \\
\hline & Pre & Post & Pre & Post & Pre & Post & Pre & Post & Pre & Post \\
\hline $\mathrm{PaO}_{2}, \mathrm{mmHg}$ & $\begin{array}{c}95 \\
(5)\end{array}$ & $\begin{array}{l}89^{*} \\
(4)\end{array}$ & $\begin{array}{l}94 \\
(4)\end{array}$ & $\begin{array}{l}96 \\
(5)\end{array}$ & $\begin{array}{l}90 \\
(3)\end{array}$ & $\begin{array}{r}100^{*} \\
(4)\end{array}$ & $\begin{array}{l}94 \\
(4)\end{array}$ & $\begin{array}{l}95 \\
(6)\end{array}$ & $\begin{array}{l}93 \\
(5)\end{array}$ & $\begin{array}{l}95 \\
(5)\end{array}$ \\
\hline $\mathrm{PaCO}_{2}, \mathrm{mmHg}$ & $\begin{array}{l}30.1 \\
(1.7)\end{array}$ & $\begin{array}{c}41.1^{*} \\
(1.9)\end{array}$ & $\begin{array}{l}32.0 \\
(1.5)\end{array}$ & $\begin{array}{l}30.7 \\
(1.7)\end{array}$ & $\begin{array}{l}29.7 \\
(1.9)\end{array}$ & $\begin{array}{c}43.1^{*} \\
(1.8)\end{array}$ & $\begin{array}{l}31.5 \\
(1.8)\end{array}$ & $\begin{array}{l}31.3 \\
(1.7)\end{array}$ & $\begin{array}{l}31.1 \\
(1.6)\end{array}$ & $\begin{array}{c}35.0^{*} \\
(1.7)\end{array}$ \\
\hline pHa & $\begin{array}{c}7.43 \\
(0.02)\end{array}$ & $\begin{array}{c}7.26^{*} \\
(0.03)\end{array}$ & $\begin{array}{c}7.39 \\
(0.03)\end{array}$ & $\begin{array}{c}7.39 \\
(0.03)\end{array}$ & $\begin{array}{c}7.44 \\
(0.02)\end{array}$ & $\begin{array}{c}7.28^{*} \\
(0.02)\end{array}$ & $\begin{array}{c}7.43 \\
(0.03)\end{array}$ & $\begin{array}{r}7.39^{*} \\
(0.02)\end{array}$ & $\begin{array}{c}7.42 \\
(0.01)\end{array}$ & $\begin{array}{c}7.35^{*} \\
(0.02)\end{array}$ \\
\hline $\mathrm{HCO}_{3}^{-}, \mathrm{mM}$ & $\begin{array}{l}20.2 \\
(0.6)\end{array}$ & $\begin{array}{c}18.9^{*} \\
(0.5)\end{array}$ & $\begin{array}{l}19.5 \\
(0.6)\end{array}$ & $\begin{array}{c}18.5^{*} \\
(0.7)\end{array}$ & $\begin{array}{l}20.5 \\
(0.7)\end{array}$ & $\begin{array}{c}22.9^{*} \\
(0.5)\end{array}$ & $\begin{array}{c}20.5 \\
(0.4)\end{array}$ & $\begin{array}{l}17.9^{*} \\
(0.6)\end{array}$ & $\begin{array}{c}20.4 \\
(0.6)\end{array}$ & $\begin{array}{c}20.0 \\
(0.5)\end{array}$ \\
\hline $\mathrm{P}_{\bar{v}} \mathrm{O}_{2}, \mathrm{mmHg}$ & $\begin{array}{l}53 \\
(3)\end{array}$ & $\begin{array}{l}60^{*} \\
(3)\end{array}$ & $\begin{array}{l}52 \\
(2)\end{array}$ & $\begin{array}{l}53 \\
(3)\end{array}$ & $\begin{array}{l}48 \\
(4)\end{array}$ & $\begin{array}{l}55^{*} \\
(3)\end{array}$ & $\begin{array}{l}49 \\
(2)\end{array}$ & $\begin{array}{l}53 \\
(3)\end{array}$ & $\begin{array}{l}52 \\
(3)\end{array}$ & $\begin{array}{l}54 \\
(2)\end{array}$ \\
\hline $\mathrm{P}_{\bar{v} C \mathrm{C}_{2}}, \mathrm{mmHg}$ & $\begin{array}{l}34.6 \\
(1.9)\end{array}$ & $\begin{array}{c}47.0^{*} \\
(2.1)\end{array}$ & $\begin{array}{l}35.4 \\
(2.0)\end{array}$ & $\begin{array}{l}34.7 \\
(1.9)\end{array}$ & $\begin{array}{l}34.1 \\
(2.0)\end{array}$ & $\begin{array}{l}48.1^{*} \\
(1.8)\end{array}$ & $\begin{array}{l}36.3 \\
(1.7)\end{array}$ & $\begin{array}{l}34.9 \\
(1.9)\end{array}$ & $\begin{array}{l}34.5 \\
(1.6)\end{array}$ & $\begin{array}{c}38.9^{*} \\
(1.8)\end{array}$ \\
\hline $\mathrm{pH} \overline{\mathbf{v}}$ & $\begin{array}{c}7.38 \\
(0.03)\end{array}$ & $\begin{array}{c}7.21^{*} \\
(0.02)\end{array}$ & $\begin{array}{c}7.36 \\
(0.02)\end{array}$ & $\begin{array}{c}7.35 \\
(0.02)\end{array}$ & $\begin{array}{c}7.41 \\
(0.03)\end{array}$ & $\begin{array}{c}7.25^{*} \\
(0.02)\end{array}$ & $\begin{array}{c}7.40 \\
(0.02)\end{array}$ & $\begin{array}{r}7.35^{*} \\
(0.03)\end{array}$ & $\begin{array}{c}7.37 \\
(0.02)\end{array}$ & $\begin{array}{c}7.31 \\
(0.03)\end{array}$ \\
\hline
\end{tabular}

Mean $\pm(\mathrm{SE})$ are presented. ${ }^{*} P<0.05$, pre vs post. $\mathrm{PO}_{2}$, partial pressure of oxygen; $\mathrm{PCO}_{2}$, partial pressure of carbon dioxide; a, arterial; $\overline{\mathrm{v}}$, mixed venous. 
Table III. Inert Gas Exchange Measurments

\begin{tabular}{|c|c|c|c|c|c|c|c|c|c|c|}
\hline & \multicolumn{2}{|c|}{ Acetazolamide } & \multicolumn{2}{|c|}{ Control } & \multicolumn{2}{|c|}{ Respiratory acidosis } & \multicolumn{2}{|c|}{ Metabolic acidosis } & \multicolumn{2}{|c|}{ DNDS } \\
\hline & Pre & Post & Pre & Post & Pre & Post & Pre & Post & Pre & Post \\
\hline \multirow[t]{2}{*}{$\log \mathrm{SD}_{\mathrm{Q}}$} & 0.60 & $0.90^{*}$ & 0.71 & 0.66 & 0.58 & 0.65 & 0.60 & 0.62 & 0.62 & 0.64 \\
\hline & $(0.06)$ & $(0.08)$ & $(0.10)$ & $(0.11)$ & $(0.06)$ & $(0.07)$ & $(0.07)$ & $(0.06)$ & $(0.06)$ & $(0.07)$ \\
\hline \multirow[t]{2}{*}{$\log \mathrm{SD}_{\mathrm{v}}$} & 0.75 & $0.83^{*}$ & 0.90 & 0.92 & 0.88 & $0.50^{*}$ & 0.79 & 0.83 & 0.73 & 0.75 \\
\hline & $(0.07)$ & $(0.09)$ & $(0.08)$ & $(0.10)$ & $(0.08)$ & $(0.07)$ & $(0.08)$ & $(0.07)$ & $(0.06)$ & $(0.07)$ \\
\hline \multirow[t]{2}{*}{$\dot{\mathrm{Q}}_{\mathrm{S}} / \dot{\mathrm{Q}}_{\mathrm{T}}, \%$} & 0.4 & 0.4 & 0.4 & 0.6 & 0.2 & 0.1 & 0.4 & 0.6 & 0.6 & 0.4 \\
\hline & $(0.1)$ & $(0.1)$ & $(0.2)$ & $(0.1)$ & $(0.1)$ & $(0.1)$ & $(0.2)$ & $(0.2)$ & $(0.1)$ & $(0.1)$ \\
\hline \multirow[t]{2}{*}{$\dot{\mathrm{V}}_{\mathrm{D}} / \dot{\mathrm{V}}_{\mathrm{T}}, \%$} & 37 & 38 & 38 & 39 & 45 & $33^{*}$ & 35 & 35 & 38 & 37 \\
\hline & (3) & (2) & (3) & (4) & (3) & (3) & (4) & (3) & (2) & (3) \\
\hline \multirow[t]{2}{*}{$(\mathrm{a}-\mathrm{A}) \mathrm{D}$ area } & 0.21 & $0.27^{*}$ & 0.24 & 0.25 & 0.21 & $0.14^{*}$ & 0.20 & 0.21 & 0.22 & 0.23 \\
\hline & $(0.02)$ & $(0.03)$ & $(0.02)$ & $(0.02)$ & $(0.02)$ & $(0.02)$ & $(0.02)$ & $(0.02)$ & $(0.03)$ & $(0.02)$ \\
\hline
\end{tabular}

Mean $\pm(\mathrm{SE})$ are presented. ${ }^{*} P<0.05$, pre vs post. $\log \mathrm{SD}_{\mathrm{Q}}$ and $\log \mathrm{SD}_{\dot{\mathrm{v}}}, \log$ standard deviation of the perfusion and ventilation distributions.

7.28 vs $7.26(P=\mathrm{NS})$. However, in contrast to acetazolamide, respiratory acidosis with $\mathrm{CO}_{2}$ inhalation resulted in significant improvements in respiratory and inert gas exchange. There was a small but significant rise in cardiac output from 5.7 to 6.4 $1 / \min (P<0.05)$, without a significant change in heart rate. There was a small but statistically significant drop in $\mathrm{O}_{2}$ consumption and $\mathrm{CO}_{2}$ production. The arterial $\mathrm{PO}_{2}$ rose significantly from 90 to $100 \mathrm{mmHg}(P<0.05)$. Peak airway pressure rose a small but statistically significant amount, 11.0 to 11.5 $\mathrm{mmHg}(P<0.05)$. There were otherwise no significant changes in temperature or hematocrit. The effects of respiratory acidosis on inert gas exchange measures of $\dot{\mathrm{V}}_{\mathrm{A}} / \mathrm{Q}$ distributions ( Table III) were principally a narrowing of the ventilation distribution, as marked by a fall in $\log \mathrm{SD}_{\dot{\mathrm{v}}}$ from 0.88 to $0.50(P$ $<0.05$ ) and a reduction in dead space from 45 to $33 \%(P$ $<0.05)$. These resulted in a reduction of $(\mathrm{a}-\mathrm{A}) \mathrm{D}$ area from 0.21 to $0.14(P<0.05)$.

Effects of metabolic acidosis. To mimic the effects of the slight metabolic acidosis (renal bicarbonaturia) that occurs with the administration of any CA inhibitor, three dogs were given a highly selective inhibitor of renal CA (to generate an alkaline diuresis and loss of bicarbonate) and three were given $0.5 \mathrm{mEq} / \mathrm{kg} \mathrm{HCl}$ to generate the same degree of metabolic acidosis without the use of a CA inhibitor. Both resulted in similar degrees of metabolic acidosis and had no significant effect on either respiratory or inert gas exchange and so their data are combined in Tables I-III. The arterial $\mathrm{pH}$ fell from 7.43 to $7.39(P<0.05)$ and the bicarbonate fell from 20.5 to $18.9 \mathrm{mM}(P<0.05)$, indicating a mild metabolic acidosis of equal magnitude to that with acetazolamide. The only signifcant change was a slight increase in cardiac output from 5.2 to $5.8 \mathrm{liter} / \mathrm{min}(P<0.05)$.

Effects of red cell anion exchange inhibition. These studies were performed to recreate a block to $\mathrm{CO}_{2}$ excretion and respiratory acidosis qualitatively similar to that with $\mathrm{CA}$ inhibition. To mimic partially the effects of slow mobilization of blood bicarbonate with acetazolamide in the generation of $\mathrm{CO}_{2}$ for diffusion into the alveoli, we inhibited the rapid red cell membrane exchange of plasma bicarbonate for red cell chloride during pulmonary capillary transit by DNDS, a reversible inhibitor of band 3 protein. This electroneutral membrane anion transporter is responsible for the classic chloride or Hamburger shift (32). In intact dogs (34) and in isolated rabbit lungs (35), red cell anion exchange inhibition reduces $\mathrm{CO}_{2}$ output by $\sim 20 \%$ in contrast to $60 \%$ with CA inhibition. The data in Table II show that DNDS caused a lesser respiratory acidosis than that with acetazolamide; $\mathrm{pH}, 7.35$ vs $7.26(P<0.05)$ and $\mathrm{PaCO}_{2}, 35$ vs $41 \mathrm{mmHg}(P<0.05)$. In contrast to acetazolamide or $\mathrm{CO}_{2}$ inhalation there were no significant changes in arterial $\mathrm{PO}_{2}$ or changes in any parameter of inert gas exchange.

Fig. 2 displays the data for a single global parameter of inert gas exchange and $\dot{\mathrm{V}}_{\mathrm{A}} / \dot{\mathrm{Q}}$ mismatch, the (a-A)D area (31), for all experimental groups. To minimize differences arising from different baselines, percent change is used instead of absolute change. In summary, only acetazolamide caused worsened $\dot{\mathrm{V}}_{\mathrm{A}} / \dot{\mathrm{Q}}$ mismatch, while the others ( time under anesthesia, metabolic acidosis, and respiratory acidosis with red cell anion exchange inhibition) were without effect. Respiratory acidosis with $\mathrm{CO}_{2}$ inhalation decreased $\dot{\mathrm{V}}_{\mathrm{A}} / \mathrm{Q}$ mismatch.

\section{Discussion}

Acetazolamide increases $\dot{V}_{A} / Q$ heterogeneity in normal lungs and this cannot be reproduced by mimicking the drug's systemic acid-base effects and alterations in blood $\mathrm{CO}_{2}$ kinetics. Although it would have been more rigorous to have inhibited only lung CA selectively, selective inhibition of lung CA is not possible in the whole animal. Therefore it was necessary to control for the effects of systemic acid-base changes and the unique pattern of $\mathrm{CO}_{2}$ excretion that occur with $\mathrm{CA}$ inhibition by using other measures to reproduce (wholly or in part) those actions of acetazolamide independent of its inhibition of lung CA.

Direct versus indirect effects of acetazolamide on $\dot{V}_{A} / \dot{Q}$ matching. The hemodynamic and metabolic data of Table I show that acetazolamide did not have any significant effects on cardiac output, airway resistance, or metabolic rate to account for the observed deterioration in $\dot{\mathrm{V}}_{\mathrm{A}} / \dot{\mathrm{Q}}$ distributions. General anesthesia is known to cause $\dot{\mathrm{V}}_{\mathrm{A}} / \mathrm{Q}$ mismatching, but in those dogs maintained under anesthesia alone for the same duration as the animals with interventions, there was no measurable worsening of $\dot{\mathrm{V}}_{\mathrm{A}} / \mathrm{Q}$ heterogeneity. More importantly, the potentially confounding effects of acetazolamide directly related to inhibition of red cell, renal, and tissue carbonic anhydrases other than the lung had to be addressed.

The respiratory acidosis which develops with red cell and 


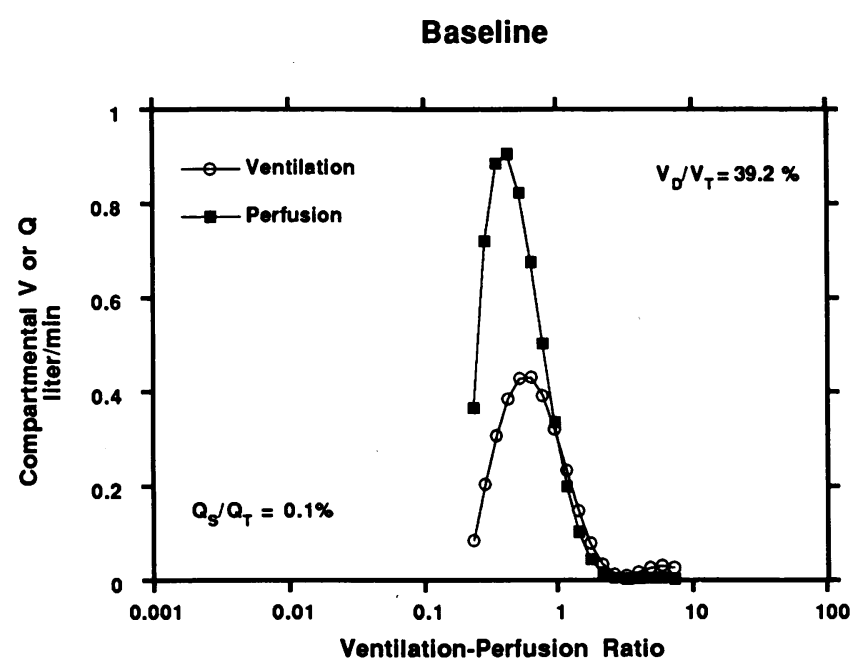

Carbonic Anhydrase Inhibition

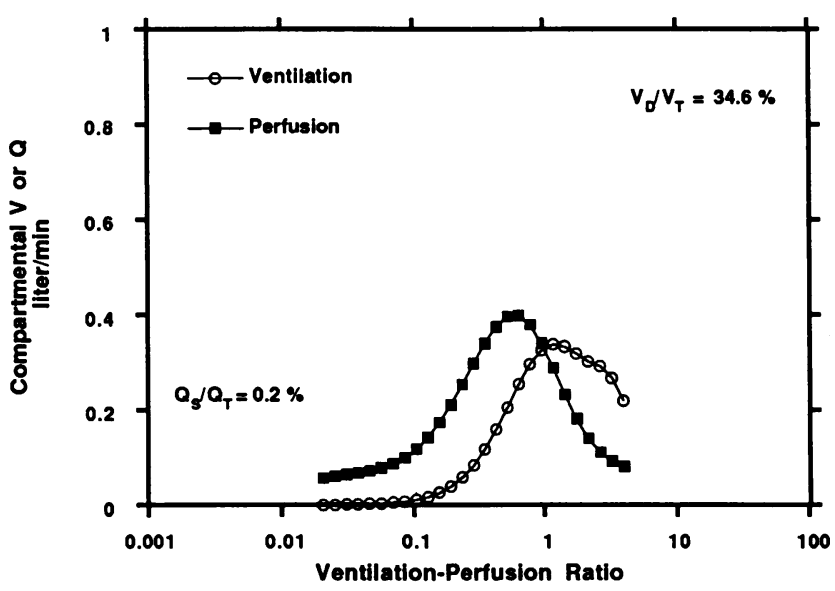

Figure 1. $\dot{\mathrm{V}}_{\mathrm{A}} / \mathrm{Q}$ distributions in a single dog before and after CA inhibition with acetazolamide. This dog showed one of the largest responses to acetazolamide. The ventilation, $\mathrm{V}$ (open circles) and perfusion, $\mathrm{Q}$ ( solid squares) distributions were broadened after acetazolamide without significant change in shunt $\left(Q_{S} / Q_{T}\right)$ or dead space ventilation $\left(V_{D} / V_{T}\right)$.

tissue CA inhibition was investigated in two ways. First, an equivalent respiratory acidosis was imposed by $\mathrm{CO}_{2}$ inhalation. This had, in fact, an opposite effect on $\dot{\mathrm{V}}_{\mathrm{A}} / \dot{\mathrm{Q}}$ heterogeneity as we have previously reported (36) and others have since confirmed (37). The effect of $\mathrm{CO}_{2}$ inhalation on $\dot{\mathrm{V}}_{\mathrm{A}} / \mathrm{Q}$ matching appears to be due to a reduction in dead space and in a narrowing of the ventilation distributions $\left(\log \mathrm{SD}_{\dot{v}}\right)$ suggesting that increased airway $\mathrm{CO}_{2}$ particularly present during inspiration causes improvements in the distribution of ventilation significant enough to improve arterial $\mathrm{Po}_{2}$ even in normal lungs. Although $\mathrm{CO}_{2}$ inhalation generates an equivalent respiratory acidosis as acetazolamide, this exogenous imposition of $\mathrm{CO}_{2}$ does not reproduce the manner in which endogenous $\mathrm{CO}_{2}$ retention develops with acetazolamide, namely, by altering the normal pattern of capillary $\mathrm{CO}_{2}$ transfer. By slowing the rate at which plasma and red cell bicarbonate can be rapidly converted to $\mathrm{CO}_{2}$ in the short transit time of capillaries, inhibition of red cell $\mathrm{CA}$ initially leads to a marked reduction in $\mathrm{CO}_{2}$

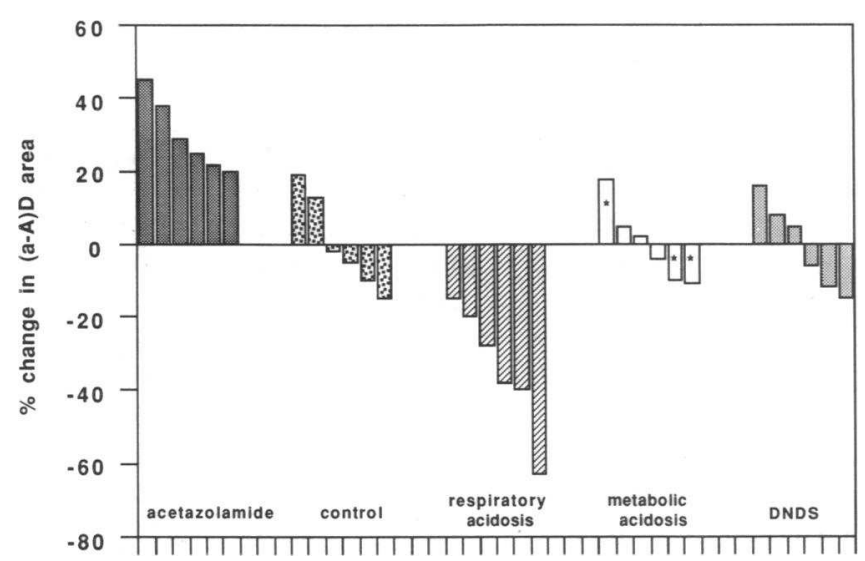

Figure 2. Individual dog data showing the percent change in the (a-A) $D$ inert gas area (arterial-alveolar inert gas difference) with acetazolamide compared to the systemic effects of acetazolamide unrelated to lung CA inhibition. A positive percent change represents worsened $\dot{\mathrm{V}}_{\mathrm{A}} / \dot{\mathrm{Q}}$ matching. In the metabolic acidosis series, those dogs given $\mathrm{HCl}$ are denoted by an asterisk.

excretion at the lung, fall in alveolar $\mathrm{PCO}_{2}$ and consequently a generalized retention $(32,33)$. As tissue, mixed venous $\mathrm{PCO}_{2}$ and the mixed venous to alveolar $\mathrm{PCO}_{2}$ gradient rise, steady state $\mathrm{CO}_{2}$ excretion returns to normal. Thus, the considerable differences between $\mathrm{CO}_{2}$ inhalation and red cell $\mathrm{CA}$ inhibition in the relationships among alveolar, airway, venous, and arterial $\mathrm{PCO}_{2} \mathrm{~s}$ and $\dot{\mathrm{V}}_{\mathrm{A}} / \dot{\mathrm{Q}}$ led us to attempt a closer approximation of the unique respiratory acidosis of red cell $\mathrm{CA}$ inhibition.

Since selective red cell CA inhibition is not possible in the whole animal, we slowed blood $\mathrm{CO}_{2}$ kinetics by inhibiting red cell band 3 protein and preventing $\mathrm{CO}_{2}$ excretion from plasma bicarbonate (32). As the data in Table III show, DNDS caused a respiratory acidosis, although of lesser magnitude because DNDS prevents only the utilization of plasma bicarbonate while acetazolamide blocks the utilization of both red cell and plasma bicarbonate. Since DNDS did not cause any $\dot{\mathrm{V}}_{\mathrm{A}} / \mathbf{Q}$ mismatching, it is unlikely that the effects of acetazolamide can be attributed solely to inhibition of red cell CA and not of lung CA.

It was also important to control for the systemic metabolic acidosis that is generated with the urinary loss of bicarbonate due to renal CA inhibition. This was tested in two ways. Neither the metabolic acidosis with selective renal CA inhibition with benzolamide nor infusion of hydrochloric acid caused any $\dot{\mathrm{V}}_{\mathrm{A}} / \mathrm{Q}$ mismatch. It should be clarified, however, that the selectivity of benzolamide for renal CA is more properly a parenchymal selectivity since many vascular capillary beds, including the lung, contain a luminal membrane bound CA isozyme on the luminal surface with access to plasma (32). Our negative results with benzolamide cannot rule out any significant participation of plasma-facing vascular endothelial membrane bound enzyme in $\dot{V}_{A} / \dot{Q}$ regulation since only three animals were studied and the very low dose was chosen to take advantage of the proximal tubule organic acid uptake mechanism to concentrate the drug in the kidney for full inhibition (28).

Proposed role for lung $C A$ in $\dot{V}_{A} / \dot{Q}$ matching. The extraordinary efficiency of normal gas exchange is determined to a great extent by the matching of regional ventilation and perfusion 
(38). Like oxygen, carbon dioxide has a number of effects in the lung which can also contribute to $\dot{\mathrm{V}}_{\mathrm{A}} / \dot{\mathrm{Q}}$ matching. A primary change in either regional ventilation or perfusion leads to opposite changes in regional ambient $\mathrm{PCO}_{2}$ and $\mathrm{PO}_{2}$; each gas alone or synergistically can initiate appropriate directional changes in the accompanying blood or gas flow. Since the biological actions of $\mathrm{CO}_{2}$ are mediated largely by resultant changes in $\mathrm{pH}$ (vide infra), more rapid matching will occur if CA is present to catalyze these acid-base reactions. The catalytic activity of lung $\mathrm{CA}$ to speed the interconversion of $\mathrm{CO}_{2}, \mathrm{H}^{+}$, and $\mathrm{HCO}_{3}^{-}$is $\sim 150-200$ times that of the uncatalyzed chemical reaction (32). Although this activity is trivial compared to the almost 20,000-fold catalytic activity of red cell CA, by virtue of its 100-fold greater concentration (33), this is still sufficient to reduce the half time of the uncatalyzed reaction from roughly $90 \mathrm{~s}$ at $37^{\circ} \mathrm{C}$ to less than a second (33).

von Euler and Liljestrand (39) proposed that local hypercapnia may play a role in controlling the distribution of pulmonary blood flow in a manner analogous to their landmark concept of regulation by local hypoxia. Since their observations that hypercapnia raises pulmonary pressure, many others have demonstrated similar effects in a variety of species including man (40). Localized increases in alveolar $\mathrm{CO}_{2}$ with unilateral administration of $\mathrm{CO}_{2}$ to one lung cause vasoconstriction and blood flow diversion (41). Only a single study has considered the time course of the response. Orchard et al. (15) found that a change in $\mathrm{CO}_{2}$ caused pulmonary artery pressure to rise within seconds (half time to full response $\sim 30 \mathrm{~s}$ ) in the presence of hypoxia, a response compatible with lung $\mathrm{CA}$ catalysis of $\mathrm{CO}_{2}$ induced $\mathrm{pH}$ changes.

$\mathrm{CO}_{2}$ also augments hypoxic pulmonary vasoconstriction (HPV) in most species (40). The kinetics of HPV are somewhat slower than the vascular and bronchial responses to $\mathrm{CO}_{2}$. Depending upon the species, half times range from 2 to $3 \mathrm{~min}$ as opposed to the $30-60$-s half-times of $\mathrm{CO}_{2}$ responses $(15,40)$. Since any change in regional ventilation or perfusion will alter local $\mathrm{O}_{2}$ and $\mathrm{CO}_{2}$ tensions oppositely, the potential for HPV synergy by $\mathrm{CO}_{2}$ exists. Thus, $\mathrm{CA}$ may play a role in rapidly setting the magnitude of any $\mathrm{CO}_{2}$ modulation of HPV. Whether CA has any role in determining HPV in the absence of $\mathrm{CO}_{2}$ changes is unexplored.

The concept of direct hypocapnic bronchoconstriction and hypercapnic bronchodilation arose from early studies in which it was noted that alveolar ventilation fell in a lung whose blood flow was reduced (42). Swenson and colleagues $(16,17)$ showed that during unilateral pulmonary occlusion in humans and dogs, changes in ventilation and airway resistance could be blocked by inhalation of $6 \% \mathrm{CO}_{2}$ and this was confirmed later at the lobar and segmental level $(43,44)$. Bronchodilation following an increase in blood flow in the isolated left lower lobe of the $\operatorname{dog}(45)$ and after inhalation of $\mathrm{CO}_{2}$ in the cat (18) have been reported. The time course of these changes in ventilation and airway resistance are rapid with responses occurring within 15 to $30 \mathrm{~s}(16,18)$ and are consistent with CA-catalyzed changes in local $\mathrm{H}^{+}$concentration. The actions of $\mathrm{CO}_{2}$ on bronchial tone appear to be local and at the level of the small airways since vagotomy and atropine $(46,47)$ and adrenergic stimulation (47) have no influence on $\mathrm{CO}_{2}$-sensitive bronchomotor tone. Measurements of small airways resistance by a wedged bronchoscope also show marked effects of $\mathrm{CO}_{2}(48)$. These are mediated by $\mathrm{pH}$ changes, since isocapnic $\mathrm{pH}$ changes are equally potent and appear to act by altering calcium uptake in airway smooth muscle (49).

The effect of $\mathrm{CO}_{2}$ on perfusion-related changes in ventilation may also be related to changes in local compliance. The original studies on pulmonary artery occlusion $(16,17)$ also revealed reductions in static compliance that could be prevented by inhalation of $\mathrm{CO}_{2}$. The basis for this effect is unknown but may be the result of alterations in terminal airwayalveolar duct constriction and/or alveolar surfactant properties. $\mathrm{CO}_{2}$-induced smooth muscle relaxation at the level of the smallest airways may be involved directly with regulation of collateral ventilation ( 50$)$. The surface tension lowering properties of surfactant may also be $\mathrm{pH}$ sensitive $(51,52)$. These studies and others demonstrate that surfactant more effectively lowers surface tension as $\mathrm{pH}$ falls. Furthermore $\mathrm{CO}_{2}$ may affect release and/or synthesis of surfactant in alveolar type II pneumocytes (53) and may alter lipid phase transitions in surfactant (54). The alveolar hypophase is a poorly buffered fluid with a pH in the range of 6.2-6.5 (55) as the result of apical acid secretion (14) involving epithelial CA (13) or acidification of surfactant containing lamellar bodies (56). Thus alveolar lining fluid is regulated to ensure that even small changes in regional $\mathrm{CO}_{2}$ delivery or elimination will cause greater variation in $\mathrm{pH}$ and a larger stimulus than would occur in a well buffered milieu.

Our experimental findings and the literature are consistent with the concept that lung $C A$ acts to enhance $\dot{V}_{A} / \dot{Q}$ matching in the face of naturally occurring variations in regional ventilation and perfusion although evidence for such fluctuations is lacking. This is due largely to the lack of any techniques with fast temporal resolution capable of making these measurements. In proposing this explanation we cannot exclude the possibility that acetazolamide in some other manner leads to greater $\dot{\mathrm{V}}_{\mathrm{A}} / \mathrm{Q}$ heterogeneity. One alternative explanation is that the drug might have nonspecific heterogenous effects on regional vascular or bronchial responsiveness (57), although our global hemodynamic and airway pressure data show no significant changes. Another is that CA inhibition might actually cause greater spontaneous regional ventilation and perfusion fluctuations and have nothing to do with the speed of compensatory matching mechanisms. At present, since we lack methods to quantitate short-term regional ventilation and perfusion changes, it is not possible to address whether CA inhibition provokes greater regional gas and blood flow fluctuations. However, in regard to whether CA inhibition alters the kinetics of compensatory matching mechanisms, we have preliminary data showing that acetazolamide increases the half-time of bronchodilation to inhaled $\mathrm{CO}_{2}$ from 15 to $60 \mathrm{~s}$ (58) and likewise increases the half time of regional ventilation redistribution following changes in lobar pulmonary artery blood flow from 75 to $160 \mathrm{~s}(59)$.

The genesis, frequency, and magnitude of fluctuations in regional ventilation and perfusion, if they occur, are unknown. The causes for temporal blood or gas flow variability may either be inherent spontaneous fluctuations or nonuniform changes in regional pleural, airway, and vascular pressures associated with body position changes and fluctuations in minute ventilation (60) and cardiac output (61). Nothing is known about temporal variations in regional ventilation, and only little is known about temporal variability in regional perfusion. Recently, we have shown by sequential injections of radiola- 
beled microspheres at 20 -min intervals that lung pieces measuring $\sim 3 \mathrm{~cm}^{3}$ display a mean coefficient of variation of roughly $17 \%$ over time $(20,21)$. Although these data in the lung do not address short-term fluctuations, such short-term temporal variability in regional blood flow in other organs has been demonstrated. The heart $(22,23)$ and skeletal muscle (24) show significant temporal variability in regional perfusion $( \pm 10-15 \%$ on the order of $30-120 \mathrm{~s})$.

If these magnitudes and cycle lengths exist in regional lung blood and gas flows, then mechanisms causing rapid, matched directional changes in regional ventilation and perfusion would lead to more efficient gas exchange. Since global measurements of inert gas exchange in humans and dogs by Wagner et al. (62) show much less temporal variability it is possible that any temporal mismatch between regional perfusion and ventilation arising from fluctuations with cycle lengths of $30-300 \mathrm{~s}$ is minimized by CA-dependent mechanisms and does not add to $\dot{V}_{A} / Q$ heterogeneity. Ultimate verification of this concept will rest upon establishing more definitive data on the magnitude and time course of naturally occurring fluctuations in regional perfusion and ventilation and showing that $\mathrm{CA}$ inhibition, in fact, slows the matching responses $(58,59)$.

\section{Acknowledgments}

We thank Mical Middaugh and Tim Tran for their excellent technical assistance throughout the course of these experiments.

This research was supported by grants HL-45571-02 and HL-12174 from the National Institutes of Health.

\section{References}

1. Lonnerholm, G. 1982. Pulmonary carbonic anhydrase in human, monkey and rat. J. Appl. Physiol. 52:352-356.

2. Lonnerholm, G., and P. J. Wistrand. 1982. Carbonic anhydrase in the fetal lung. Pediatr. Res. 16:407-411.

3. Sugai, N., Y. Ninomiya, and T. Oosaki. 1981. Localization of carbonic anhydrase in the rat lung. Histochemistry. 72:415-424.

4. Lutjen-Drecoll, E., M. Eichorn, and E. H. Barany. 1985. Carbonic anhydrase in epithelia and fenestrated juxtacapillaries of Macaa fasicularis. Acta Physiol. Scand. 124:295-307.

5. Effros, R. M., R. S. Y. Chang, and P. Silverman. 1978. Acceleration of plasma bicarbonate conversion to carbon dioxide by pulmonary carbonic anhydrase. Science (Wash. DC). 199:427-429.

6. Klocke, R. A. 1980 . Equilibrium of $\mathrm{CO}_{2}$ reactions in the pulmonary capillary. J. Appl. Physiol. 48:972-976.

7. Bidani, A., S. J. Mathew, and E. D. Crandall. 1983. Pulmonary vascular carbonic anhydrase activity. J. Appl. Physiol. 55:75-83.

8. Nioka, S., R. P. Henry, and R. E. Forster. 1988. Total CA activity in isolated perfused guinea pig by $18-\mathrm{O}$ exchange method. J. Appl. Physiol. 65:2236-2244.

9. Enns, T., and E. P. Hill. 1983. $\mathrm{CO}_{2}$ diffusion capacity in isolated dog lung lobes and the role of carbonic anhydrase. J. Appl. Physiol. 54:483-490.

10. Klocke, R. A. 1978. Catalysis of $\mathrm{CO}_{2}$ reactions by lung carbonic anhydrase. J. Appl. Physiol. 44:882-888.

11. Crandall, E. D., and J. E. O'Brasky. 1978. Direct evidence for participation of rat lung carbonic anhydrase in $\mathrm{CO}_{2}$ reactions. J. Clin. Invest. 62:618-622.

12. Farhi, L. E., J. L. Plewes, and A. J. Olszowka. 1976. Lung carbonic anhydrase, $\mathrm{CO}_{2}$ stores and $\mathrm{CO}_{2}$ transport. Ciba Found. Symp. 38:235-249.

13. Davis, T. A., G. Gause, A. M. Perks, H. Kuck, and S. Cassin. 1989. The effects of acetazolamide on fetal lung liquid secretion. FASEB (Fed. Am. Soc. Exp. Biol.) J. 3:A1140.

14. Lubman, R. L., S. I. Danto, and E. D. Crandall. 1989. Evidence for active $\mathrm{H}^{+}$secretion by rat alveolar epithelial cells. Am. J. Physiol. 257:L438-L445.

15. Orchard, C. H., R. Sanchez de Leon, and M. K. Sykes. 1983. The relationship between hypoxic pulmonary vasoconstriction and arterial oxygenation in the intact dog. J. Physiol. (Lond.). 338:61-74.

16. Swenson, E. W., T. N. Finley, and S. V. Guzman. 1961. Unilateral hypo- ventilation in man during temporary occlusion of one pulmonary artery. J. Clin. Invest. 40:828-835.

17. Severinghaus, J. W., E. W. Swenson, T. N. Finley, M. T. Lategola, and J. Williams. 1961. Unilateral hypoventilation produced in dogs by occluding one pulmonary artery. J. Appl. Physiol. 16:53-60.

18. Delpierre, S., Y. Jammes, N. Mei, and M. J. Mathiot. 1980. Mise en evidence de l'origine vagale reflexe des effets bronchoconstricteurs du in vivo chez le chat. J. Physiol. (Paris). 76:889-891.

19. Sterling, G. M. 1968. The mechanism of bronchoconstriction due to hypocapnia in man. Clin. Sci. (Lond.). 34:277-285.

20. Glenny, R. W., W. J. E. Lamm, R. K. Albert, and T. H. Robertson. 1991. Gravity is a minor determinant of pulmonary blood flow distribution. J. Appl. Physiol. 71:620-629.

21. Glenny, R. W., N. L. Polissar, and H. T. Robertson. 1993. Temporal heterogeneity of regional pulmonary perfusion is spatially clustered. FASEB (Fed. Am. Soc. Exp. Biol.) J. 7:788a. (Abstr.).

22. King, R. B., and J. B. Bassingthwaighte. 1989. Temporal fluctuations in myocardial blood flows. Pfluegers Arch. Eur. J. Physiol. 413:336-342.

23. Iverson, P. O. 1992. Evidence for long-term fluctuations in regional blood flow within the rabbit left ventricle. Acta Physiol. Scand. 146:329-339.

24. Marconi, C., N. Heisler, M. Meyer, H. Weitz, D. R. Pendergast, P. Cerretelli, and J. Piiper. 1988. Blood flow distribution and its temporal variability in stimulated dog gastrocnemius muscle. Respir. Physiol. 74:1-14.

25. Severinghaus, J. W. 1966. Blood gas calculator. J. Appl. Physiol. 21:11081116.

26. Wagner, P. D., H. A. Saltzman, and J. B. West. 1974. Measurement of continuous distributions of ventilation-perfusion ratios: theory. J. Appl. Physiol. 36:588-599.

27. Wagner, P. D., P. F. Naumann, and R. B. Lavaruso. 1974. Simultaneous measurement by eight foreign gases in blood by gas chromatography. J. Appl. Physiol. 36:600-605.

28. Maren, T. H. 1967. Carbonic anhydrase: chemistry, physiology and inhibition. Physiol. Rev. 47:597-781.

29. Froblich, O. 1982. The external anion binding site of the human erythrocyte anion trans-porter: DNDS binding and competition with chloride. $J$. Membr. Biol. 65:111-123.

30. Evans, J. W., and P. D. Wagner. 1977. Limits on $\dot{V}_{A} / Q$ distributions from experimental inert gas elimination. J. Appl. Physiol. 42:889-898.

31. Hlastala, M. P. 1984. Multiple inert gas elimination technique. J. Appl. Physiol. 56:1-7.

32. Bidani, A. 1991. Analysis of abnormalities of capillary $\mathrm{CO}_{2}$ exchange in vivo. J. Appl. Physiol. 70:1686-1699.

33. Swenson, E. R., and T. H. Maren. 1978. A quantitative analysis of $\mathrm{CO}_{2}$ transport at rest and during maximal exercise. Respir. Physiol. 35:129-159.

34. Swenson, E. R., J. Gronlund, J. Ohlsson, and M. P. Hlastala. 1993. In vivo contributions of carbonic anhydrase and red cell band 3 protein to pulmonary gas exchange. J. Appl. Physiol. 74:838-848.

35. Crandall, E. D., S. J. Mathew, R. S. Fleischer, H. I. Winter, and A. Bidani. 1981. Effects of inhibition of $\mathrm{RBC} \mathrm{HCO}_{3}^{-} / \mathrm{Cl}^{-}$exchange on $\mathrm{CO}_{2}$ excretion and downstream pH disequilibrium in isolated rat lungs. $J$. Clin. Invest. 68:853-862.

36. Swenson, E. R., H. T. Robertson, M. E. Middaugh, and M. P. Hlastala. 1988. Inspiration of $\mathrm{CO}_{2}$ improves ventilation-perfusion matching in the dog. FASEB (Fed. Am. Soc. Exp. Biol.) J. 2:A924.

37. Tsukimoto, K., J. P. Arcos, W. Schaffartzik, P. D. Wagner, and J. B. West. 1990. Effect of common dead space on $\dot{V}_{A} / Q$ distribution in the dog. J. Appl. Physiol. 68:2488-2493.

38. Farhi, L. E. 1986. Ventilation-perfusion relationships. In Handbook of Physiology, Section 3: The Respiratory System, Volume 4. Gas Exchange. L. E. Farhi and S. M. Marsh, editors. American Physiological Society, Bethesda, MD. 199-215.

39. von Euler, U. S., and G. Liljestrand. 1946. Observations on the pulmonary arterial blood pressure in the cat. Acta Physiol. Scand. 12:301-320.

40. Dawson, C. A. 1984. Role of pulmonary vasomotion in physiology of the lung. Physiol. Rev. 64:544-616.

41. Twining, R. H., V. Lopez-Majano, H. N. Wagner, V. Cherniack, and R. E. Dutton. 1968. Effect of regional hypercapnia on the distribution of pulmonary blood flow in man. Johns Hopkins Med. J. 123:95-103.

42. Venrath, H. R., R. Rotthoff, H. Valentin, and W. Bolt. 1952. Bronchospirografische Untersuchungen bei Durchblutungsstorungen im kleinen Kreislauf. Beitr. Klin. Tuberk. 107:291-299.

43. Levy, S. E., M. Stein, R. S. Totten, S. Wessler, I. Bruderman, and E. D. Robin. 1965. Ventilation-perfusion abnormalities in experimental pulmonary embolism. J. Clin. Invest. 44:1699-1707.

44. Levy, S. E., and D. H. Simmons. 1974. Redistribution of alveolar ventilation following pulmonary thromboembolism in the dog. J. Appl. Physiol. 36:6068.

45. Samanek, M., and D. M. Aviado. 1967. Interrelationships between pulmonary blood flow and bronchomotor tone: $\mathrm{PO}_{2}$ and $\mathrm{PCO}_{2}$. J. Appl. Physiol. 22:719730. 
46. Ingram, R. H. 1975. Effects of airway versus arterial $\mathrm{CO}_{2}$ in vivo changes on lung mechanics in dogs. J. Appl. Physiol. 38:603-607.

47. Coon, R. L., E. J. Zuperku, and J. P. Kampine. 1980. Effect of sympathetic nerve stimulation on hypocapnic airway constriction. Proc. Soc. Exp. Biol. Med. 164:63-68.

48. Smith, L. C., C. Inner, P. B. Terry, H. A. Menkes, and R. J. Traystman. 1979. Effects of methacholine and hypocapnia on airways and collateral ventilation in dogs. J. Appl. Physiol. 46:966-972.

49. Twort, C. H. C., and I. R. Cameron. 1968. Effects of $\mathrm{PCO}_{2}, \mathrm{pH}$ and extracellular calcium on contraction of airway smooth muscle from cats. Respir. Physiol. 66:259-267.

50. Traystman, R. J., P. B. Terry, and H. A. Menkes. 1978. Carbon dioxide: a major determinant of collateral ventilation. J. Appl. Physiol. 45:69-74.

51. Colacicco, G., M. K. Basu, and I. Scarpelli. 1976. pH, temperature, humidity, and the dynamic force-area curve of dipalmityol lecithin. Respir. Physiol. 27:169-186.

52. Wildeboer-Venema, F. 1984. Influences of nitrogen, air and alveolar gas upon surface tension of lung surfactant. Respir. Physiol. 58:1-14.

53. Shepard, J. W., G. F. Dolan, and S. Y. Yu. 1982. Factors regulating lamellar body volume density of type II pneumocytes in excised dog lung. J. Appl. Physiol. 53:555-562.

54. Ecanow, B., and M. I. Blake. 1978. Significance of surfactant transitions in the respiratory process. Naturwissenschaften. 65:68-69.
55. Nielson, D. W., J. Goerke, and J. A. Clements. 1981. Alveolar subphase $\mathrm{pH}$ in the lungs of anesthetized rabbits. Proc. Natl. Acad. Sci. USA. 78:71197123.

56. Chander, A., R. G. Johnson, J. Reicherter, and A. B. Fisher. 1986. Lung lamellar bodies maintain an acidic internal pH. J. Biol. Chem. 261:6126-6131.

57. O'Donnell, W. J., M. Rosenberg, R. W. Niven, J. M. Drazen, and E. Israel. 1992. Acetazolamide and furosemide attentuate asthma induced by hyperventilation of cold, dry air. Am. Rev. Resp. Dis. 146:1518-1523.

58. Swenson, E. R. 1991. The role of lung carbonic anhydrase in $\dot{V} / \dot{Q}$ matching. In Carbonic Anhydrase: From Biochemistry and Genetics to Physiology and Clinical Medicine. F. Botre, G. Gros, and B. T. Storey, editors. VCH Verlagsgesellschaft mbH, Weinheim, Germany. 393-403.

59. Swenson, E. R., M. M. Graham, and M. P. Hlastala. 1993. CA inhibition slows kinetics of ventilation redistribution following imposed changes in pulmonary blood flow: effects on $\dot{V} / \dot{Q}$ matching. Am. Rev. Respir. Dis. 147:937a. (Abstr.).

60. Lenfant, C. 1967. Time dependent variations of pulmonary gas exchange in normal man at rest. J. Appl. Physiol. 22:675-684.

61. Sackner, M. A., R. Dougherty, N. Atkins, D. Culver, D. Poole, F. Stout, and A. Wanner. 1973. Techniques of pulmonary capillary blood flow determination. Eur. Bull. Physiopath. Resp. 9:1189-1202.

62. Wagner, P. D., G. Hedenstierna, G. Bylin, and L. Lagerstrand. 1987 Reproducibility of the multiple inert gas elimination technique. J. Appl. Physiol. 62:1740-1746. 